\title{
PEMUPUKAN NPK MAJEMUK PADA BIBIT JABON MERAH (Anthocephalus macrophyllus (Roxb.) Havil)
}

\section{THE USE OF COMPOUND NPK FERTILIZER ON RED JABON (Anthocephalus macrophyllus (Roxb.) Havil) SEEDLING}

\author{
Faisal S. Luhulima1), Marthen. T. Lasut(2), Reynold. P. Kainde ${ }^{2)}$ dan Alfonsius. Thomas ${ }^{2)}$ \\ 1)Alumni Fakultas Pertanian Unsrat Manado \\ 2)Dosen Fakultas Pertanian Unsrat Manado
}

\begin{abstract}
Various doses of NPK fertilization could increase plant growth. This research studied the effect of NPK compound fertilizer with some kind of dose on the growth of seedlings of red jabon. This research was conducted at the Laboratory of Silviculture Faculty of Agriculture, University of Sam Rarulangi which lasted from May until June 2012, The objectives of this study were to determine the effect of compound NPK fertilizers on the growth of seedlings of red jabon. The research used experimental design of Randomized Block Design (RBD), Each treatment was replicated 5 times and each replication consisted of 5 red jabon seedlings. The treatments being given were: (1) without fertilizer (control), (2) $1 \mathrm{~g}$ of NPKI plant, (3) $2 \mathrm{~g}$ of NPK/plant, (4) $3 \mathrm{~g}$ of NPK/plant and (5) $4 \mathrm{~g}$ of NPK/plant. The results of this research showed that compound fertilizer NPK influence to high growth, diameter, number of leaves, root volume and dry weight of seedlings red jabon canopy. NPK fertilizer with a dose of $3 \mathrm{~g} /$ plant $(\mathrm{D})$ can increase height growth, diameter and number of leaves. While the parameters of the root volume and dry weight of the canopy, NPK treatment media with $4 \mathrm{~g} / \mathrm{plant}(\mathrm{E})$ gives better results.
\end{abstract}

Keywords : NPK fertilization, growth seedling, red jabon

\section{ABSTRAK}

Pemupukan NPK dengan berbagai dosis dapat meningkatkan pertumbuhan tanaman. Dalam penelitian ini dipelajari pengaruh pemupukan majemuk NPK dengan beberapa macam dosis terhadap pertumbuhan bibit jabon merah. Penelitian ini dilaksanakan di Laboratorium Silvikultur Fakultas Pertanian Universitas Sam Rarulangi yang berlangsung mulai Mei s/d Juni 2012. Tujuan dari penelitian ini ialah untuk mengetahui pengaruh pemupukan majemuk NPK terhadap pertumbuhan bibit jabon merah. Penelitian ini menggunakan metode eksperimen Rancangan Acak Kelompok (RAK), setiap perlakuan diulang sebanyak 5 kali dan setiap ulangan terdiri atas 6 bibit jabon. Perlakuan yang diberikan adalah : (1) tanpa pupuk (kontrol), (2) pupuk NPK 1 gram/tanaman, (3) pupuk NPK 2 gram/tanaman, (4) pupuk NPK 3 gram/tanaman dan (5) pupuk NPK 4 gram/tanaman. Hasil penelitian menunjukkan bahwa terdapat pengaruh dosis pupuk majemuk NPK terhadap pertumbuhan tinggi, diameter, jumlah daun, volume akar dan berat kering tajuk bibit jabon merah. Pemupukan NPK dengan dosis 3 gram/tanaman (D) dapat meningkatkan pertumbuhan tinggi, diameter dan jumlah daun. Sedangkan pada parameter volume akar dan berat kering tajuk, media dengan perlakuan NPK 4 gram/tanaman (E) memberikan hasil yang lebih baik.

Kata kunci : pemupukan NPK, pertumbuhan bibit, jabon merah 


\section{PENDAHULUAN}

Pasokan kayu dari hutan alam yang kian menurun dan semakin banyaknya lahan marginal, mengharuskan adanya pembangunan hutan tanaman industri (HTI) maupun hutan rakyat untuk tetap dapat memenuhi permintaan komoditas kayu yang semakin meningkat. Menurut data Departemen Kehutanan RI tahun 2005, kapasitas industri dan konsumen diperkirakan membutuhkan bahan baku kayu sebesar 63,48 juta meter kubik per tahun, sementara kemampuan produksi hutan (suplai) hanya sekitar 22,8 juta meter kubik per tahun. Hal ini mengakibatkan terjadi kesenjangan kebutuhan bahan baku sebesar 40,60 juta meter kubik per tahun.

Prokduktifitas hutan harus ditingkatkan dengan merestorasi hutan. Program restorasi seperti pengembangan Hutan Tanaman Industri (HTI) maupun hutan rakyat harus ditunjang oleh tersedianya bibit dalam jumlah dan mutu yang baik. Bibit yang bermutu memiliki potensi untuk bertumbuh dan berkembang pada kondisi lingkungan yang beragam.

Jabon merah merupakan jenis tumbuhan asli Indonesia berhabitus pohon dengan pertumbuhan batang lurus dengan percabangan monopodial dan termasuk jenis pohon yang pertumbuhannya cepat. Oleh karena itu berpotensi untuk dikembangkan dalam pembangunan hutan tanaman maupun untuk tujuan lainnya. Penyediaan bibit yang berkualitas merupakan aspek yang penting dan pengetahuan tentang bagaimana menghasilkan bibit yang bermutu perlu diketahui. Salah satu aspek adalah pemupukan media tumbuh bibit jabon.

Pupuk merupakan salah satu input sangat esensial dalam proses produksi tanaman. Tanpa pupuk, penggunaan input seperti bibit unggul, air dan tenaga kerja, hanya akan memberikan manfaat minimal sehingga produktifitas tanaman dan pendapatan petani akan rendah. Oleh karena itu, ketersediaan pupuk secara enam tepat, yaitu tepat jenis, tepat jumlah, tepat mutu, tepat lokasi, tepat waktu dan tepat harga, merupakan hal yang mutlak harus dipenuhi.

Jabon merah (Anthocephalus macrophyllus (Roxb.) Havil) merupakan jenis tanaman hutan yang cepat tumbuh dari famili Rubiaceae dan memiliki banyak kegunaan. Jabon merah dapat tumbuh subur di hutan tropis dengan ketinggian 50-1000 meter dpl. Jabon merah hanya dapat ditemukan di Indonesia bagian timur yaitu pulau Maluku, sebagian Sulawesi, dan papua yang dikenal dengan sebutan samama atau karumama. Pohon jabon dapat tumbuh tinggi mencapai 40 meter dengan tinggi bebas cabang 30 meter, serta dapat mencapai diameter $40-50 \mathrm{~cm}$. Pohon jabon memiliki batang berbentuk bulat dan lurus. Jabon merah dapat hidup diantara jenis tanaman lain dan dominan dalam menyerap unsur hara dalam tanah (Mulyana, dkk., 2011).

Penelitian ini bertujuan untuk mengetahui pengaruh pemupukan majemuk NPK terhadap pertumbuhan bibit jabon merah.

\section{METODE PENELITIAN}

Penelitian ini dilaksanakan di Rumah Kaca Laboratorium Silvukultur Fakultas Pertanian Universitas Sam Ratulangi Manado. Penelitian ini dilaksanakan selama 2 bulan yaitu Mei sampai Juni 2012.

Alat yang digunakan dalam penelitian ini adalah gunting, mistar, jangka sorong, timbangan analitik, gelas ukur, polibag ukuran $22 \times 25 \mathrm{~cm}$, sprayer, alat tulis, kamera dan laptop. Bahan yang digunakan dalam penelitian ini adalah bibit jabon merah, tanah, pasir, pupuk kandang ayam, pupuk NPK Compaction (15-15-15) dan pestisida.

\section{Prosedur Kerja \\ Penyiapan Media}

Sebelum media dicampur terlebih dahulu dikeringudarakan selama 3-4 hari. Kemudian tanah dan pupuk kandang ditumbuk sampai halus lalu dicampur.

\section{Penyiapan Bibit}

Bibit sebelum digunakan terlebih dahulu disortir berdasarkan jumlah daunnya yaitu 4 pasang daun, serta bebas dari serangan hama dan penyakit.

\section{Penyapihan}

Bibit yang disapih adalah bibit yang telah berumur 4 bulan dan memiliki 4 pasang daun. Penyapihan dilakukan pada pagi hari di bawah naungan (paranet). Penanaman dalam polibag dilakukan 
dengan cara manual yaitu membuat lubang tanam 7-10 cm dengan tangan, lalu bibit ditanam dalam lubang tersebut hingga bagian akar tertanam.

\section{Proses Adaptasi dan Pemeliharaan}

Setelah penyapihan, bibit jabon diletakkan dalam rumah kaca selama 7 hari di bawah naungan (paranet). Penyiraman dilakukan 2 kali sehari yaitu pagi dan sore hari dengan menggunakan sprayer agar media tetap lembab. Selain itu juga dilakukan pembersihan gulma dan perbaikan posisi polibag. Setelah masa adaptasi dalam rumah kaca selesai, bibit jabon dipindahkan ke lapangan. Masa adaptasi bibit jabon di lapangan juga selama 7 hari.

\section{Pengendalian Hama dan Penyakit}

Untuk mengantisipasi bibit jabon dari serangan hama dan penyakit maka, dilakukan pemantauan secara berkala. Selain itu juga, dilakukan penyemprotan pestisida apabila ada serangan hama dan penyakit.

\section{Pemupukan}

Pemupukan dilakukan setiap dua minggu sekali. Penaburan pupuk dilakukan setelah pengambilan data awal. Pupuk ditabur dengan jarak $3-5 \mathrm{~cm}$ dari batang.

\section{Pengukuran dan Pengamatan}

Parameter yang diamati adalah tinggi tanaman, diameter tanaman, jumlah daun, volume akar dan berat kering tajuk. Pengukuran tinggi bibit dilakukan setelah proses adaptasi bibit di lapangan yaitu selama 7 hari. Pengukuran dilakukan setiap minggu selama 2 bulan. Tinggi diukur mulai dari pangkal batang atau $1 \mathrm{~cm}$ dari permukaan tanah hingga titik tumbuh pucuk bibit. Pengukuran diameter bibit dilakukan dengan menggunakan jangka sorong, diukur pada pangkal batang sekitar $3 \mathrm{~cm}$ dari permukaan tanah. Pengukuran dilakukan setiap minggu selama dua bulan. Rata-rata bibit jabon yang diamati memiliki 4 pasang daun. Pengamatan dilakukan setiap minggu untuk mengetahui pertambahan jumlah daun. Pengukuran volume akar dilaku- kan pada akhir pengamatan. Sampel tanaman dipotong tepat diantara batas pangkal batang dan akar kemudian akar tersebut dibersihkan dari sisasisa media yang menempel dengan menggunakan air. Setelah itu akar dimasukkan ke dalam gelas ukur yang sudah terlebih dahulu diisi dengan air. Dari hasil pengukuran tersebut didapat data volume akar dari bibit jabon. Sampel tanaman dipotong mulai dari bagian pangkal batang hingga pucuk dan dibungkus dengan kertas koran, kemudian dioven pada suhu $75^{\circ} \mathrm{C}$ selama 72 jam, dimana dilakukan penimbangan setiap 24 jam sekali sampai tercapai bobot kering yang konstan. Dari hasil penimbangan didapat data bobot kering tajuk bibit jabon.

Rancangan penelitian yang digunakan adalah metode Rancangan Acak Kelompok (RAK), dengan 5 perlakuan dan 5 ulangan. Setiap perlakuan diulang sebanyak 5 kali dan setiap ulangan terdiri atas 6 tanaman. Dengan demikian terdapat 150 bibit jabon merah yang ditanam.

Perlakuan yang diberikan adalah: $\mathrm{A}=$ tanpa pupuk NPK (kontrol); $B=$ pupuk NPK 1 gram/tanaman; $C=$ pupuk NPK 2 gram/tanaman; $D=$ pupuk NPK 3 gram/tanaman; $E=$ pupuk NPK 4 gram/tanaman

Data hasil penelitian ini dianalisa dengan menggunakan Sidik Ragam (Analisa Of Variance ) dan apabila ada yang beda nyata dilanjutkan dengan uji BNT $5 \%$.

\section{HASIL DAN PEMBAHASAN}

\section{Tinggi Bibit Jabon Merah}

Tinggi bibit dapat digunakan sebagai indikator maupun parameter pertumbuhan untuk mengukur pengaruh lingkungan atau perlakuan yang diterapkan (Sitompul dan Guritno,1995). Hasil sidik ragam menunjukan bahwa pemberian pupuk NPK dengan berbagai dosis memberikan pengaruh nyata terhadap pertumbuhan tinggi bibit jabon. Karena itu, untuk mengetahui jenis perlakuan yang berbeda nyata pada penggunaan berbagai dosis pupuk NPK maka dilanjutkan dengan uji BNT (Tabel 1). 
Tabel 1. Pengaruh Pemupukan NPK terhadap Tinggi Bibit Jabon Merah

(Table 1. The Influence of NPK Fertilization to High of Red Jabon Seedling)

\begin{tabular}{ccccccccc}
\hline \multirow{2}{*}{ Perlakuan } & \multicolumn{7}{c}{ Rata-rata Tinggi Bibit Jabon Pada Umur (cm) } \\
\cline { 2 - 9 } & $14 \mathrm{HST}$ & $21 \mathrm{HST}$ & $28 \mathrm{HST}$ & $35 \mathrm{HST}$ & $42 \mathrm{HST}$ & $49 \mathrm{HST}$ & $56 \mathrm{HST}$ & $63 \mathrm{HST}$ \\
\hline $\mathrm{A}$ & $12.04 \mathrm{a}$ & $12.94 \mathrm{a}$ & $13.96 \mathrm{a}$ & $15.44 \mathrm{a}$ & $16.68 \mathrm{a}$ & $18.22 \mathrm{a}$ & $20.22 \mathrm{a}$ & $22.74 \mathrm{a}$ \\
$\mathrm{B}$ & $12.28 \mathrm{ab}$ & $13.44 \mathrm{~b}$ & $14.56 \mathrm{~b}$ & $16.74 \mathrm{~b}$ & $18.52 \mathrm{a}$ & $20.66 \mathrm{a}$ & $23.52 \mathrm{a}$ & $26.60 \mathrm{a}$ \\
$\mathrm{C}$ & $12.38 \mathrm{~b}$ & $13.66 \mathrm{bc}$ & $15.42 \mathrm{c}$ & $18.36 \mathrm{c}$ & $21.12 \mathrm{~b}$ & $24.18 \mathrm{~b}$ & $28.18 \mathrm{~b}$ & $32.46 \mathrm{~b}$ \\
$\mathrm{D}$ & $12.22 \mathrm{ab}$ & $13.46 \mathrm{bc}$ & $15.32 \mathrm{c}$ & $18.60 \mathrm{c}$ & $22.96 \mathrm{~b}$ & $26.84 \mathrm{c}$ & $31.92 \mathrm{c}$ & $36.92 \mathrm{c}$ \\
$\mathrm{E}$ & $12.42 \mathrm{~b}$ & $13.84 \mathrm{c}$ & $15.68 \mathrm{c}$ & $18.78 \mathrm{c}$ & $22.94 \mathrm{~b}$ & $27.34 \mathrm{c}$ & $33.18 \mathrm{c}$ & $38.96 \mathrm{c}$ \\
BNT 5\% & 0.24 & 0.38 & 0.51 & 1.21 & 1.95 & 2.87 & 3.57 & 4.31
\end{tabular}

Ket: Angka rata-rata yang diikuti oleh huruf yang sama pada kolom yang sama menunjukan tidak berbeda nyata menurut uji BNT 5\%.

Selama 8 minggu pengamatan terdapat pertambahan tinggi bibit jabon. Berdasarkan Tabel 1 dapat diketahui bahwa bibit jabon pada umur 14 HST dengan perlakuan NPK 4 gram/tanaman $(E)$ menghasilkan nilai rata-rata pertumbuhan tinggi yang paling besar yaitu $12,42 \mathrm{~cm}$. Perlakuan ini berbeda nyata dengan perlakuan NPK 0 gram/tanaman atau kontrol (A) tetapi, tidak berbeda nyata dengan perlakuan NPK 1 gram/tanaman (B), 2 gam/tanaman (C), 3 gram/tanaman (D) dan 4 gram/tanaman (E). Hal ini diduga karena bibit jabon berada pada fase pertumbuhan aktif sehingga pertumbuhan relatif sama pada semua perlakuan kecuali konrol (A). Perlakuan NPK dengan dosis 0 gram/tanaman atau kontrol (A) menghasilkan nilai rata-rata pertumbuhan tinggi terkecil yaitu $12,04 \mathrm{~cm}$, perlakuan ini berbeda nyata dengan perlakuan NPK 2 gram/tanaman (C) dan 4 gram/tanaman $(E)$ tetapi, tidak berbeda nyata dengan perlakuan NPK 1 gram/tanaman (B) dan 3 gram/tanaman (D). Hal ini diduga karena pada perlakuan NPK 0 gram/tanaman atau kontrol (A) tidak mendapat input dari pupuk anorganik sehingga tanaman tidak mendapat suplai unsur hara yang dibutuhkan untuk menunjang pertumbuhannya dimana mengakibatkan pertumbuhan tanaman menjadi terhambat.

Pada umur 21 HST hingga 35 HST media dengan perlakuan NPK 4 gram/tanaman (E) menghasilkan nilai rata-rata pertumbuhan tinggi terbesar yaitu $13,84-18,78 \mathrm{~cm}$, perlakuan ini berbeda nyata dengan perlakuan NPK 0 gram/tanaman atau kontrol (A) dan 1 gram/tanaman (B) tetapi, tidak berbeda nyata dengan perlakuan NPK 2 gram/tanaman (C) dan 3 gram/tanaman (D). Perlakuan NPK dengan dosis 0 gram/tanaman atau kontrol (A) menghasilkan nilai rata-rata pertumbuhan tinggi terkecil yaitu $12,94-15,44 \mathrm{~cm}$, perlakuan ini berbeda nyata dengan perlakuan NPK 1 gram/tanaman (B), 2 gram/tanaman (C), 3 gram/tanaman (D) dan 4 gram/tanaman (E). Sedangkan pada umur 42 hingga 63 HST media dengan perlakuan NPK 4 gram/tanaman $(E)$ mengahasilkan nilai rata-rata pertumbuhan tinggi terbesar yaitu 22,94-38,96 cm, perlakuan ini berbeda nyata dengan perlakuan NPK 0 gram/tanaman atau kontrol (A), 1 gram/tanaman (B) dan 2 gram/tanaman (C) tetapi, tidak berbeda nyata dengan perlakuan NPK 3 gram/tanaman (D). Perlakuan NPK dengan dosis 0 gram/tanaman atau kontrol (A) menghasilkan nilai rata-rata pertumbuhan tinggi terkecil yaitu 16,68-22,74 cm, perlakuan ini berbeda nyata dengan perlakuan NPK 2 gram/tanaman (C), 3 gram/tanaman (D) dan 4 gram/tanaman (E). Perlakuan NPK dengan dosis 3 gram/tanaman (C) menghasilkan nilai rata-rata pertumbuhan tinggi yang berbeda nyata terhadap kontrol $(A)$, tetapi perlakuan ini memberikan pengaruh yang lebih rendah dibandingkan dengan perlakuan NPK 4 gram/tanaman (E). Hal ini karena adanya penambahan input yang berasal dari pupuk NPK semakin meningkat sesuai dengan pertambahan dosis pupuk sehingga tinggi tanaman juga ikut meningkat.

Bibit jabon pada umur 14 HST hingga 63 HST dengan perlakuan NPK 3 gram/tanaman (D) tidak memberikan pengaruh yang nyata terhadap perlakuan pupuk NPK 4 gram/tanaman (E) tetapi, perlakuan ini memberikan pengaruh yang nyata terhadap perlakuan NPK 0 gram/tanaman atau kontrol (A). Hal ini diduga karena pemberian pupuk NPK 
dengan dosis 3 gram/tanaman (D) telah mencukupi kekurangan unsur hara, sehingga pertumbuhan tinggi bibit jabon dapat tumbuh dengan baik. Untuk memenuhi kebutuhan tanaman, kita harus bisa menyediakan unsur hara dalam jumlah yang diperkirakan cukup dan seimbang (Parnata, 2004). Ditambahkan oleh Petrokimia (2005), agar tanaman dapat tumbuh dengan baik dan menghasilkan hasil yang tinggi, diperlukan unsur hara yang cukup dan seimbang. Pemberian pupuk NPK terhadap tanah dapat berpengaruh baik pada kandungan hara tanah dan dapat berpengaruh baik bagi pertumbuhan tanaman karena unsur hara makro yang terdapat dalam unsur $\mathrm{N}, \mathrm{P}$ dan $\mathrm{K}$ diperlukan bagi pertumbuhan dan perkembangan tanaman yang akan diambil oleh tanaman dalam bentuk anion dan kation (Sutejo, 2002).

Riap tinggi menunjukkan perubahan tinggi bibit jabon yang diperoleh dari perhitungan selisih tinggi bibit jabon akhir pengamatan dengan bibit jabon awal pengamatan. Untuk melihat laju pertumbuhan tinggi bibit jabon per minggu dapat dilihat pada Gambar 1.

Berdasarkan Gambar 1 semua perlakuan yang digunakan menunjukkan pertambahan tinggi setiap kali pengukuran. Hal ini dapat disebabkan adanya faktor genetik dan lingkungan (ruang tumbuh dan penerimaan cahaya matahari) serta kemampuan tanaman beradaptasi dan tumbuh baik pada suatu media tanam. Selain itu juga, Sitompul dan Guritno (1995) menyatakan bahwa sebagai parameter pengaruh lingkungan, tinggi tanaman sensitif terhadap faktor cahaya.

Semua perlakuan yang diberikan menunjukkan perkembangan tinggi setiap minggunya bervariasi. Pada umur 14 HST hingga 56 HST media dengan perlakuan NPK 4 gram/tanaman (E) menunjukkan perkembangan tinggi selalu meningkat setiap minggunya tetapi, pada umur 63 HST perkembangan tinggi perlakuan ini cenderung menurun dan mencapai titik tertinggi pada umur $56 \mathrm{HST}(5,9 \mathrm{~cm})$. Sementara pada perlakuan NPK 3 gram/tanaman (D) menunjukkan perkembangan tinggi selalu meningkat dari umur 14 HST hingga 42 HST tetapi, pada umur 49 HST dan 63 HST perkembangan tinggi perlakuan ini cenderung menurun dan mencapai titik tertinggi pada umur $56 \mathrm{HST}(5,1 \mathrm{~cm})$. Hal ini diduga karena bibit jabon telah mengalami kejenuhan hara sehingga pada umur 63 HST perkembangan tinggi cenderung menurun.

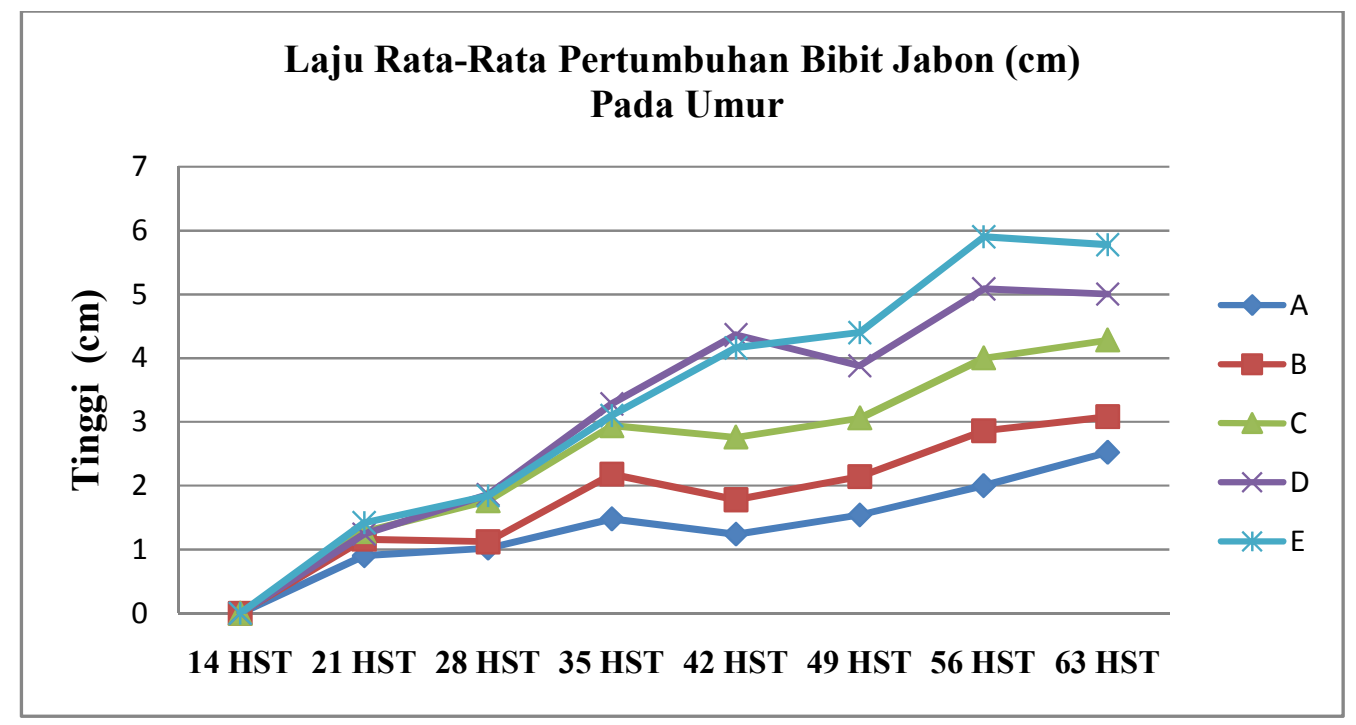

Gambar 1. Laju Rata-rata Pertumbuhan Tinggi Bibit Jabon Merah pada Setiap Waktu Pengukuran (Figure 1. Average Rate of Jabon Merah High Growth Each Time Measuring) 


\section{Diameter Bibit Jabon Merah}

Hasil sidik ragam menunjukkan bahwa semua perlakuan dosis pupuk NPK pada media yang digunakan memberikan pengaruh tidak nyata terhadap diameter batang pada umur 14 HST hingga 35 HST (Tabel 2). Pengaruh pemupukan terlihat nyata saat bibit jabon berumur 42 HST hingga 63 HST, maka dilanjutkan dengan uji BNT (Tabel 2).

Pemberian pupuk NPK tidak berpengaruh nyata (memberikan pengaruh yang sama) terhadap pertumbuhan diameter bibit jabon pada umur 14 HST hingga 35 HST. Hal ini disebabkan karena rata-rata setiap peningkatan pertumbuhan diameter setiap minggu hasilnya hampir sama sehingga pada taraf uji 0,05 tidak berpengaruh nyata. Selain itu juga pengaruh yang sama terhadap pertumbuhan diameter bibit jabon pada umur 14 HST hingga 35 HST disebabkan oleh beberapa faktor luar selain pupuk anorganik yang diberikan. Pertumbuhan tanaman dipengaruhi oleh proses fisiologis yang terjadi didalam tubuh tanaman tersebut, yaitu proses fotosintesis, respirasi, translokasi, dan penyerapan air serta mineral (Handayani 2009). Proses fisiologis di atas dipengaruhi oleh faktor lingkungan seperti sinar matahari, tanah, angin, dan cuaca.

Pada umur 42 HST media dengan perlakuan NPK 3 gram/tanaman (D) menghasilkan nilai rata-rata pertumbuhan diameter yang paling besar yaitu $1.04 \mathrm{~cm}$, perlakuan ini berbeda nyata dengan perlakuana NPK 0 gram/tanaman atau kontrol (A), 1 gram/tanaman (B) dan 2 gram/tanaman (C) tetapi, tidak berbeda nyata dengan perlakuan NPK 4 gram/tanaman (D). Perlakuan NPK dengan dosis 0 gram/tanaman atau kontrol (A) menghasilkan nilai rata-rata pertumbuhan diameter terkecil dan berbeda nyata dengan perlakuan lainnya yaitu sebesar $0.91 \mathrm{~cm}$. Hal ini diduga karena pada perlakuan NPK 0 gram/tanaman atau kontrol (A) tidak mendapat input dari pupuk anorganik sehingga tanaman tidak mendapat suplai unsur hara yang dibutuhkan untuk menunjang pertumbuhannya dimana mengakibatkan pertumbuhan tanaman menjadi terhambat.

Bibit jabon pada umur 42 HST hingga 63 HST dengan perlakuan pupuk NPK 1 gram/tanaman (B) memberikan pengaruh yang tidak nyata terhadap perlakuan NPK 2 gram/tanaman (C) tetapi, perlakuan ini memberikan pengaruh yang nyata terhadap perlakuan NPK 0 gram/tanaman atau kontrol (A), 3 gram/tanaman (D) dan $4 \mathrm{gram} /$ tanaman (E). Pada umur 42 HST hingga $63 \mathrm{HST}$ media dengan perlakuan NPK 3 gram/tanman (D) memberikan pengaruh yang tidak nyata terhadap perlakuan NPK 4 gram/tanamn (E) tetapi, perlakuan ini memberikan pengaruh yang nyata terhadap perlakuan lainnya. Hal ini diduga karena rentang dosis yang rendah antara perlakuan NPK 3 gram/tanaman (D) dengan 4 gram/tanmanan (E) sehingga rata-rata pertambahan tinggi tanaman setiap minggunya tidak berbeda nyata.

Tabel 2. Pengaruh Pemupukan NPK Terhadap Diameter Bibit Jabon Merah

(Table 2. The Influence of NPK Fertilization to Diameter of Red Jabon Seedling)

\begin{tabular}{|c|c|c|c|c|c|c|c|c|}
\hline \multirow{2}{*}{ Perlakuan } & \multicolumn{8}{|c|}{ Rata-rata Diameter Jabon Pada Umur (cm) } \\
\hline & $14 \mathrm{HST}$ & $21 \mathrm{HST}$ & $28 \mathrm{HST}$ & $35 \mathrm{HST}$ & $42 \mathrm{HST}$ & 49 HST & $56 \mathrm{HST}$ & $63 \mathrm{HST}$ \\
\hline A & 0.47 & 0.60 & 0.73 & 0.83 & $0.91 \mathrm{a}$ & $0.99 \mathrm{a}$ & $1.07 \mathrm{a}$ & $1.14 \mathrm{a}$ \\
\hline B & 0.47 & 0.61 & 0.74 & 0.86 & $0.98 b$ & $1.05 \mathrm{ab}$ & $1.15 b$ & $1.25 b$ \\
\hline C & 0.48 & 0.59 & 0.73 & 0.86 & $0.98 b$ & $1.09 \mathrm{~b}$ & $1.20 \mathrm{~b}$ & $1.32 \mathrm{~b}$ \\
\hline D & 0.47 & 0.60 & 0.77 & 0.89 & $1.04 \mathrm{c}$ & $1.18 \mathrm{c}$ & $1.32 \mathrm{c}$ & $1.44 \mathrm{c}$ \\
\hline$E$ & 0.48 & 0.61 & 0.76 & 0.89 & $1.03 \mathrm{c}$ & $1.19 \mathrm{c}$ & $1.32 \mathrm{c}$ & $1.44 \mathrm{c}$ \\
\hline BNT $5 \%=$ & - & - & - & - & 0.05 & 0.06 & 0.05 & 0.07 \\
\hline
\end{tabular}


Pertambahan diameter merupakan pertumbuhan sekunder pada tanaman. Sel parenkim batang yang berada di antara ikatan pembuluh tanaman mengalami pertumbuhan menjadi kambium intervasis. Kambium intravasis membentuk lingkaran tahun dengan bentuk konsentris. Kambium yang berada di sebelah dalam jaringan kulit yang berfungsi sebagai pelindung, terbentuk akibat ketidakseimbangan antara permbentukan xilem dan floem yang lebih cepat dari pertumbuhan kulit batang (Anita, 2009).

\section{Jumlah Daun Bibit Jabon Merah}

Hasil sidik ragam menunjukkan bahwa perlakuan NPK dengan berbagai dosis pada media yang digunakan tidak memberikan pengaruh yang nyata terhadap pertumbuhan jumlah daun bibit jabon merah pada umur 14 HST hingga 56 HST. Pengaruh pemupukan NPK terlihat nyata pada saat bibit jabon berumur 63 HST, maka dilanjutkan dengan uji BNT (Tabel 3).

Perlakuan pemupukan NPK dengan berbagai dosis yang digunakan tidak memberikan pengaruh yang nyata terhadap pertumbuhan jumlah daun saat bibit jabon berumur 14 HST hingga 56 HST. Pengaruh pemupukan NPK terlihat nyata pada saat bibit jabon berumur 63 HST. Hal ini disebabkan karena rata-rata setiap peningkatan pertumbuhan daun setiap minggu hasilnya hampir sama sehingga pada taraf uji 0,05 tidak berpengaruh nyata. Selain itu juga bibit jabon berada pada fase pertumbuhan aktif sehingga pertumbuhan relatif sama pada semua perlakuan.

Pada umur 63 HST media dengan perlakuan NPK 4 gram/tanaman (D) menghasilkan nilai rata-rata pertumbuhan jumlah daun terbesar yaitu sebesar 15.8 helai, perlakuan ini berbeda nyata dengan perlakuan NPK 0 gram/tanaman atau kontrol (A), 1 gram/tanaman (B) dan 2 gram/tanaman (C) tetapi, tidak berbeda nyata dengan perlakuan NPK 3 gram/tanaman (D). Hal ini diduga karena pemberian dosis 3 gram/tanaman pupuk NPK telah mencukupi kekurangan unsur hara, sehingga pertumbuhan jumlah daun bibit jabon dapat tumbuh dengan baik.

Perlakuan NPK dengan dosis 1 gram/tanaman (B) menghasilkan nilai rata-rata pertumbuhan jumlah daun terkecil yaitu 14.2 helai, perlakuan ini berbeda nyata dengan perlakuan NPK 3 gam/tanaman (D) dan 4 gram/tanaman (E) tetapi, tidak berbeda nyata dengan perlakuan NPK 0 gram/tanaman atau kontrol (A) dan 2 gram/tanaman (C). Hal ini diduga karena adanya penambahan input yang berasal dari pupuk NPK yang berguna untuk pertumbuhan pucuk dan daun semakin meningkat sesuai dengan pertambahan dosis pupuk sehingga pertumbuhan jumlah daun tanaman juga ikut meningkat.

Tabel 3. Pengaruh Pemupukan NPK Terhadap Jumlah Daun Bibit Jabon Merah

(Table 3. The Influence of NPK Fertilization to Number of Leaf of Red Jabon Seedling)

\begin{tabular}{ccccccccc}
\hline \multirow{2}{*}{ Perlakuan } & \multicolumn{7}{c}{ Rata-rata Jumlah Daun Jabon Pada Umur (helai) } \\
\cline { 2 - 9 } & 14 HST & 21 HST & 28 HST & 35 HST & 42 HST & 49 HST & 56 HST & 63 HST \\
\hline A & 8 & 10 & 10 & 11.4 & 12 & 13.4 & 14 & $14.8 \mathrm{a}$ \\
B & 8 & 9.4 & 10.4 & 11.4 & 12 & 13 & 13.4 & $14.2 \mathrm{a}$ \\
C & 8 & 9.4 & 10.2 & 11.2 & 12.4 & 13.2 & 13.8 & $14.8 \mathrm{a}$ \\
D & 8 & 8.6 & 10.2 & 11 & 12.4 & 13.2 & 14.2 & $15.6 \mathrm{~b}$ \\
E & 8 & 9.6 & 10.4 & 11.8 & 12.8 & 13.8 & 14.4 & $15.8 \mathrm{~b}$ \\
BNT 5\% = & - & - & - & - & - & - & - & 0.89 \\
\hline Ket: Angka rata-rata yang diikuti oleh huruf yang sama pada kolom yang sama menunjukkan tidak berbeda nyata \\
menurut uji BNT 5\%.
\end{tabular}




\section{Volume Akar Bibit Jabon Merah}

Hasil sidik ragam pada Tabel 4 menunjukkan bahwa semua perlakuan dosis pupuk NPK pada media yang digunakan memberikan pengaruh nyata terhadap volume akar bibit jabon pada sidik ragam dengan selang kepercayaan $95 \%$. Untuk mengetahui perlakuan yang terbaik maka dilakukan dengan uji BNT (Tabel 4).

Berdasarkan hasil uji BNT pada Tabel 4 dapat diketahui bahwa perlakuan NPK dengan dosis 4 gram/tanaman (E) menghasilkan nilai rata-rata volume akar yang paling besar dan berbeda nyata dengan perlakuan lainnya yaitu sebesar $374,22 \mathrm{~cm}$. Perlakuan NPK dengan dosis 0 gram/tanaman atau kontrol (A) menghasilkan nilai rata-rata volume akar terkecil yaitu $123,34 \mathrm{~cm}$. Perlakuan NPK dengan dosis 1 gram/tanaman (B), 2 gram/tanaman (C), dan $3 \mathrm{gram} / \mathrm{tanaman}$ (D) menghasilkan nilai ratarata volume akar yang berbeda nyata terhadap kontrol (A), tetapi perlakuan ini memberikan pengaruh yang lebih rendah dibandingkan dengan perlakuan pupuk NPK 4 gram/tanaman (E). Hal ini diduga karena unsur $\mathrm{N}, \mathrm{P}$ dan $\mathrm{K}$ yang berguna untuk merangsang dan mempercepat pertumbuhan akar tanaman semakin meningkat sesuai dengan pertambahan dosis pupuk sehingga akar tanaman semakin banyak yang secara langsung turut meningkatkan volume akar.

Pupuk NPK Compaction juga mengandung unsur Mg. Peran Magnesium diketahui dari keberadaannya pada pusat rantai molekul klorofil (Mengel and Kirkby, 1987), Selanjutnya dikatakan, $\mathrm{Mg}^{2+}$ dibutuhkan dalam proses fisiologi. Menurut Marschner (1986), laju fotosintesis lebih lambat pada tanaman yang kekurangan Mg. Bahan terlarut anorganik yang diserap dari tanah oleh selsel akar yang hidup terbawa ke atas pada aliran transpirasi sampai mencapai daun atau hantaran dalam xylem, Selanjutnya bahan utama dari daun berupa karbohidrat yang dihasilkan oleh fotosintesis ditranlokasikan ke bawah dan lebih sering ke akar yang membutuhkan jumlah besar karbohidrat (Loveless, 1987).

\section{Berat Kering Tajuk Bibit Jabon Merah}

Hasil sidik ragam menunjukkan bahwa semua perlakuan penambahan pupuk NPK dengan berbagai dosis pada media yang digunakan memberikan pengaruh yang nyata terhadap berat kering bibit jabon pada sidik ragam dengan selang kepercayaan $95 \%$, maka dilanjutkan dengan uji BNT (Tabel 5).

Tabel 4. Pengaruh Pemupukan NPK terhadap Volume Akar Bibit Jabon Merah

(Table 4. The Influence of NPK Fertilization to Root Volume of Red Jabon Seedling)

\begin{tabular}{cc}
\hline Perlakuan & Rata-rata $\left(\mathrm{cm}^{3}\right)$ \\
\hline A & $123.34 \mathrm{a}$ \\
B & $231.91 \mathrm{bc}$ \\
C & $211.88 \mathrm{~b}$ \\
D & $279.35 \mathrm{c}$ \\
E & $374.22 \mathrm{~d}$ \\
BNT $5 \%$ & 50.21 \\
\hline
\end{tabular}

Ket: Angka rata-rata yang diikuti oleh huruf yang sama menunjukan tidak berbeda nyata menurut uji BNT 5\%.

Tabel 5. Pengaruh Pemupukan NPK Terhadap Berat Kering Tajuk Bibit Jabon Merah (Table 5. The Influence of NPK Fertilization to Dry Weight of Shoot of Red Jabon Seedling)

\begin{tabular}{cc}
\hline Perlakuan & Rata-rata (gram) \\
\hline A & $25.03 \mathrm{a}$ \\
B & $32.63 \mathrm{~b}$ \\
C & $41.97 \mathrm{c}$ \\
D & $49.23 \mathrm{~d}$ \\
E & $57.13 \mathrm{e}$ \\
BNT $5 \%$ & 4.14 \\
\hline
\end{tabular}

Ket: Angka rata-rata yang diikuti oleh huruf yang sama menunjukan tidak berbeda nyata menurut uji BNT 5\%. 
Dari hasil pengamatan selama 8 minggu, dapat dilihat bahwa pemberian pupuk NPK dengan berbagai dosis berpengaruh secara nyata terhadap berat kering bibt jabon. Dari Tabel 5 terlihat adanya pengaruh nyata pada berat kering bibit jabon, karena perbedaan pemberian pupuk NPK dengan berbagai dosis pada media.

Berat kering bibit jabon pada media dengan perlakuan NPK 4 gram/tanaman (E) menghasilkan nilai rata-rata berat kering yang paling besar dan berbeda nyata dengan perlakuan lainnya yaitu sebesar 57,13 gram. Perlakuan NPK dengan dosis 0 gram/tanaman atau kotrol (A) menghasilkan nilai rata-rata berat kering terkecil yaitu 25,03 gram. Perlakuan NPK dengan dosis 1 gram/tanaman (B), 2 gram/tanaman (C) dan 3 gram/tanaman (D) menghasilkan nilai rata-rata berat kering yang berbeda nyata terhadap kontrol $(A)$, tetapi perlakuan ini memberikan pengaruh yang lebih rendah dibandingkan dengan perlakuan pupuk NPK 4 gram/tanaman (E). Hal ini diduga karena pertumbuhan tinggi dan jumlah daun bibit jabon dengan perlakuan pupuk NPK 4 gram/tanaman (E) lebih tinggi dibandingkan dengan perlakuan lainnya. Tinggi tanaman dan jumlah daun berpengaruh pada berat kering tajuk tanaman. Semakin besar tinggi tanaman dan semakin banyak jumlah daun, maka berat kering akan meningkat.

Berat kering menunjukkan taksiran (berat) tanaman relatif yang mudah diukur dan merupakan integrasi dari semua peristiwa yang dialami tanaman sebelumnya sehingga merupakan indikator pertumbuhan yang paling representatif untuk menampilkan penampilan keseluruhan pertumbuhan tanaman atau suatu organ tertentu (Sitompul dan Guritno 1995). Berat kering tanaman atau biomassa tanaman meliputi semua bahan tanaman yang secara kasar berasal dari hasil fotosintesis, serapan unsur hara, dan air yang diolah melaui proses biosintesis. Biomassa mencerminkan efisiensi interaksi proses fisiologis dengan lingkungannya, dan dinilai sebagai manifestasi dari semua proses dan peristiwa yang terjadi dalam pertumbuhan tanaman (Sitompul dan Guritno 1995).

\section{KESIMPULAN DAN SARAN}

\section{Kesimpulan}

Pemupukan NPK dengan beberapa dosis dapat meningkatkan pertumbuhan bibit jabon merah. Pemupukan NPK berpengaruh nyata pada diameter bibit jabon pada umur 42 HST-63 HST dan jumlah daun pada umur 63 HST. Pemupukan NPK dengan dosis 3 gram/tanaman (D) dapat meningkatkan pertumbuhan tinggi, diameter dan jumlah daun lebih baik dibandingkan dengan perlakuan NPK 0 gram/ tanaman atau kontrol (A), 1 gram/tanaman (B), 2 gram/tanaman (C) dan 4 gram/tanaman (E). Sedangkan pada parameter volume akar dan berat kering, media dengan perlakuan NPK 4 gram/tanaman memberikan hasil yang lebih baik dibandingkan dengan perlakuan lainnya.

\section{Saran}

Perlu dilakukan penelitian lanjutan mengenai pemberian pupuk NPK Compaction dengan waktu penelitian lebih lama dan dosis lebih ditingkatkan untuk mendapatkan hasil pertumbuhan bibit jabon merah yang lebih baik.

Perlu dilakukan penelitian lanjutan mengenai pemberian pupuk NPK Compaction dengan variabel pengamatan yang lain seperti luas daun dan berat kering total.

\section{DAFTAR PUSTAKA}

Anita, N.Y. 2009. Faktor yang Mempengaruhi Pertumbuhan dan Perkembangan Tanaman. http://ninityulianita.wordpress. com. (akses 28 Juli 2012).

Handayani, M. 2009. Pengaruh Dosis Pupuk NPK dan Kompos Terhadap Pertumbuhan Bibit Salam (Eugenia polyantha Wight). Skripsi. Departemen Silvikultur. Fakultas Kehutanan Institut Pertanian Bogor.

Loveless, A.R. 1987. Prinsip-prinsip Biologi Tumbuhan untuk Daerah Tropis. P.T. Gramedia. Jakarta. 
Mulyana, D., C. Asmarahman dan I. Fahmi. 2011. Mengenal Kayu Jabon Merah dan Putih (236 h). Panduan Lengkap Bisnis dan Bertanam Kayu Jabon. Agromedia Pustaka. Jakarta. 142 hal.

Marschner, H. 1986. Mineral Nutrition of Higher Plants. Academic Press Limited. San Diego.

Mengel and Kirkby. 1987. Prunciple of Plant Nutrition. International Potash Institute. Switzerland.
Parnata, A. S. 2004. Pupuk Organik Cair, Aplikasi dan Manfaatnya. Agromedia Pustaka. Jakarta.

Petrokimia. 2005. Phonska, Pupuk Majemuk NPK. PT Petrokimia. Gersik.

Sitompul, S. M., B. Guritno. 1995. Analisis Pertumbuhan Tanaman. Yogyakarta: Gadjah Mada University Press.

Sutejo, M. 2002. Pupuk dan Cara Pemupukan. Rineka Cipta, Jakarta. 